DOI: https://doi.org/10.32838/2523-4803/70-2-34

УДК 330:101

\title{
Кравченко М.В.
}

кандидат економічних наук, доцент, доцент кафедри обліку, оподаткування та управління фінансово-економічною безпекою,

Дніпровський державний аграрно-економічний університет

\section{Kravchenko Mykola}

Dnipro State Agrarian and Economic University

\section{МОНІТОРИНГ ІННОВАЦІЙНО-ІНВЕСТИЦИЙНОГО ЗАБЕЗПЕЧЕННЯ ЕКОНОМІЧНОЇ БЕЗПЕКИ АГРАРНОГО СЕКТОРУ}

\begin{abstract}
Принцииповою особливістю розвитку аграрного виробниитва є взаємозв'язок природних, біологічних, технологічних, організаційних та соціальних факторів. Це значною мірою посилює появу ризиків, щзо негативно впливатимуть на виробництво, його економічну ефективність, фінансові результати та розвиток аграрного сектору, щзо може призводити до зниження конкурентоспроможності та фінансової стабільності агровиробників. Результативність діяльності виробників аграрного сектору повною мірою залежить від якості оцінювання ризиків, точності планування, прогнозування та уникнення ситуацій, щуо зможуть привести до економічних втрат. Аналіз ризикової ситуації та попередження загроз мають давати змогу вибирати оптимальні рішення щзодо розвитку аграрного виробництва. Це дасть змогу не тільки захищати діяльність суб'єктів господарювання від негативних впливів, але й отримувати додатковий прибуток. Формування економічної безпеки має стати однією з визначальних складових частин системи забезпечення розвитку аграрного сектору. При изьому кониепиія убезпечення економічної безпеки розвитку аграрного виробництва має розглядатись як окремий процес системи комплексного підходу до вирішення проблемних питань їх захищеності від ризику та подолання загроз. Це повністю вказує на те, щчо процес формування економічної безпеки розвитку аграрного сектору має стратегічний характер.
\end{abstract}

Ключові слова: інновації, економічна безпека, аграрне підприємство, аналітичне забезпечення, інвестииії, оптимізація.

Постановка проблеми. Важливий інструментарій забезпечення економічної безпеки розвитку аграрного сектору складають інвестиції та інновації, запровадження та реалізація яких на основі державної підтримки даватиме можливості виробникам аграрної продукції бути конкурентоспроможними, виявляти, оцінювати загрози та ризики, запобігати появі нових, отже, певною мірою проводити контроль над ними.

3 цих позицій визначення актуальності й постановки дослідницьких завдань у статті формування концепції інноваційно-інвестиційного забезпечення економічної безпеки розвитку аграрного сектору $\epsilon$ вагомим завданням сьогодення.

Аналіз останніх досліджень і публікацій. Щодо теоретичних аспектів системи економічної безпеки, то цій проблематиці присвячено багато наукових праць вітчизняних і зарубіжних учених. Серед зарубіжних науковців можна відзначити В.В. Архипова, О.А. Бородіна, Д.Л. Ламберта, Л.П. Гончаренка, Т.Є. Кочергіну, Р.А. Караллі. Значення системи економічної безпеки вивчали такі вітчизняні вчені, як Т.Г. Васильців, Я.А. Жаліло, Є.А. Олєйніков, А.І. Паламарчук,
В.С. Пономаренко, А.В. Козаченко, В.П. Пономарьов, В.П. Мартинюк, Т.Г. Сухорукова, Г.А. Пастернак-Таранушенко, С.I. Пирожков, В.І. Щелкунов.

Праці цих учених мають високу науково-теоретичну й практичну цінність, оскільки складають фундаментальний і методологічний апарат та визначають основні напрями подальших наукових досліджень у цій сфері задля поглиблення, вдосконалення та всебічного розвитку розуміння економічної безпеки як однієї з фундаментальних категорій економічної науки. Отже, важливість досліджень організації та функціонування системи економічної безпеки підприємств аграрного сектору зумовлює актуальність теми статті [1, с. 7-10].

Формулювання цілей статті. Мета статті полягає у вивченні ефективності функціонування системи економічної безпеки аграрного сектору та пошуку шляхів покращення інноваційно-інвестиційного клімату аграрної галузі в країні.

Для досягнення поставленої мети необхідно вирішити низку таких завдань:

- розгляд теоретико-методичних засад організації системи економічної безпеки аграрного сектору; 
- аналіз стану економічної безпеки в АПК;

- розроблення шляхів покращення організації та функціонування системи фінансово-економічної безпеки аграрного сектору.

Виклад основного матеріалу. В сучасних умовах невизначеності, де все кожного дня змінюється під впливом світової фінансово-економічної кризи, підприємства АПК потрібно трактувати як відкриту систему, що неодмінно має взаємодію з різними елементами зовнішнього середовища, такими як інші підприємства, банки, організації, що належать до соціально-політичних та економічних інституцій. Для того щоби підвищити рівень економічної безпеки, агропромислового комплексу необхідно впровадити нові якісні рішення щодо сфери економічної безпеки, щоб реального підвищити їі рівень.

Механізм управління забезпеченням фінансової безпеки суб'єктів господарювання потребує множини взаємопов'язаних дій, що об'єднуються в системний підхід до підтримки фінансової безпеки підприємств, тобто управління на всіх стадіях виробництва, а саме управління цілями, завданнями відповідно до визначеної місії; пошук проблеми, усвідомлення потреби іiі вирішення, діагностика, контролювання, моніторинг та прийняття рішень щодо необхідності забезпечення фінансової безпеки суб' єкта господарювання [2, с. 17].

Оскільки аграрний сектор 3 кожним роком стає гнучким, не всі галузі фінансової безпеки підприємства перебувають на достатньому рівні, немає відділу, який би займався економічною безпекою, виникає необхідність створення відділу з питань забезпечення економічної безпеки, який би займався підтримкою та покращенням галузей фінансово-економічної безпеки на аграрних підприємствах. До його компетенцій будуть входить:

- розроблення, затвердження нормативно-правових актів, які забезпечують економічну безпеку у підрозділах підприємства, а також контроль за їх виконанням;

- виконання інших завдань, що покладені керівництвом підприємства щодо забезпечення економічної безпеки;

- підтримка взаємозв'язку 3 правоохоронними органами;

- координація діяльності підрозділів економічної безпеки, надання їм будь-якої методичної допомоги;

- вжиття зовнішніх та внутрішніх заходів з одержання інформації, які входять до компетенції підрозділу, а також ведення інформаційно-аналітичної роботи;

- аналізування загроз для діяльності підприємства та своєчасне доведення отриманих даних керівництву підприємства, щоб воно могло прийняти якісне управлінське рішення;

- швидке повідомлення керівництва підприємства та підрозділу економічної безпеки про вірогідне відхилення від стандартів економічної безпеки;

- негайне вжиття заходів щодо протидії негативним впливам на фінансово-економічну діяльність під- приємства, сумісна дія підприємства із зазначених питань 3 правоохоронними та спеціальними службами, органами влади та управління, іншими зовнішніми суб'єктами у сфері економічної безпеки.

У відділі, наприклад, буде працювати три людини, між якими будуть розподілені галузі економічної безпеки. Так, наприклад, перша людина візьме на себе фінансову та політико-правову галузь; друга буде займатись інтелектуальною, кадровою та інформаційною, екологічною; третя візьме силову та техніко-технологічну галузі.

Алгоритм інноваційного забезпечення фінансової безпеки аграрного сектору може включати такі елементи:

1) отримання даних про об'єкт, що потребує захисту, а саме отримання даних та усвідомлення їх щодо того, що саме перебуває у фінансовій небезпеці й негайно потребує захисту;

2) усвідомлення факту загрози, тобто визначення причинно-наслідкових зв'язків загроз, а також визначення того, який вони мають механізм дії або як можуть подіяти на об'єкт, якими шляхами та засобами можна уникнути цих загроз;

3) усвідомлення потреби захисту, тобто прийняття управлінського рішення щодо фінансової безпеки підприємства, визначення величини небезпеки, ухвалення того, яких саме заходів, у якій послідовності необхідно вживати за ступенем виникнення загрози; на цьому етапі необхідно розробляти концепцію фінансової безпеки на основі науково- теоретичних та практичних знань;

4) розроблення теоретичних основ фінансової безпеки підприємств, тобто визначення загальної методики щодо підтримки фінансової безпеки підприємств;

5) аналізування механізмів розвитку фінансової безпеки аграрного сектору, що дає можливість усвідомити прорахунки, здійснені в процесі забезпечення фінансової безпеки підприємств, та впроваджувати більш ефективні методи;

6) контролювання процесу забезпечення фінансової безпеки підприємства, тобто систематизація дій щодо моніторингу на всіх стадіях виробничо-господарської діяльності.

Оскільки під час проведення характеристики організаційної роботи було виявлено, що найбільш вразливою складовою частиною $є$ силова, яка відповідає за забезпечення фізичної та моральної безпеки співробітників, гарантування безпеки майна та капіталу підприємства, гарантування безпеки інформаційного середовища підприємства, то пропонуємо посилити їі шляхом забезпечення охорони приміщень, устаткувань, продукції, технічних засобів та працівників підприємства. Реалізувати це можна через використання відеоспостереження, охоронної сигналізація для приміщень, пожежної сигналізації, системи пожежогасіння, установки автоматичних воріт, використання устаткувань для обмеження доступу в приміщення [3, с. 59-65]. 
Однак для постійного, стабільного функціонування та розвитку системи економічної безпеки аграрних підприємств потрібно налагодити та посилити захист від внутрішніх та зовнішніх загроз. Через це організація системи економічної безпеки має починатися з покращення взаємозв'язку між усіма рівнями безпеки, але все це $є$ можливим тільки за фінансової, нормативної, методичної, інвестиційної, інформаційної та законодавчої підтримки держави.

На жаль, у нашій країні законодавство займається лише окремим регулюванням положень із забезпечення продовольчої безпеки, а щодо регулювання забезпечення системи економічної безпеки аграрних підприємств, то його як такого взагалі немає, через що не можна чітко описати можливості та організацію системи економічної безпеки аграрного сектору.

Непереривний економічний розвиток аграрного сектору підтримує шанси до збереження ефективного виробництва їх власної продукції в умовах збереження належних пропорцій свого внутрішнього розвитку та збалансованості 3 оптимальним розвитком його системи економічної безпеки, яка 3 ним взаємодіє, а також систем економічного характеру, а саме екологічної та соціальної.

Дотримання цих етапів формування поєднується зі стратегічними цілями державної аграрної політики України, а саме частини щодо перетворення галузі сільського господарства на високоефективний, конкурентоспроможний сектор економіки держави та комплексного розвитку сільських територій [4, с. 34-39].

Це все говорить про те, що питання організації та функціонування системи економічної безпеки аграрних підприємств мають базуватись на основі державної підтримки, що повинна будуватись на основі комплексу урядових програм та заходів, які спрямовані на підвищення ефективності та збільшення прибутковості сільськогосподарського виробництва, а саме створення інституціональної бази для безперервного функціонування діяльності суб'єктів аграрного сектору, збільшення платоспроможності, ліквідності, зменшення податкового тиску для досягнення достатнього рівня рентабельності.

Діючою, ефективною та результативною державна підтримка може вважатися, коли вона в повному обсязі задовольняє всі економічні та соціальні інтереси аграрного сектору.

Для того щоби підприємства АПК розвивались, необхідно, крім коштів на функціонування, виділити кошти на поточне забезпечення його економічної безпеки. Тільки-но починаються процеси розвитку, небезпека постійно пропорційно наростає у зв'язку зі стрімкішим рухом та розхитуванням системи.

Задля забезпечення економічної безпеки на всіх рівнях аграрного сектору мають здійснюватися структурування та комбінування елементів системи економічної безпеки.

Перманентна інтенсифікація факторів, що загрожують економічній безпеці підприємства та обумовлюють його депресивний розвиток, робить доречним створення системи моніторингу економічної безпеки на підприємстві задля завчасного попередження небезпеки, що загрожує, та вжиття необхідних заходів задля ефективного захисту та протидії цим небезпекам. Система моніторингу економічних небезпек буде складатися з чотирьох етапів, які займатимуться взаємодоповнюючими завданнями, такими як діагностика допустимих меж відхилення, прогнозування наслідків дії загрозливих факторів, виявлення тенденцій та процесів, визначення причин.

Основні етапи постійного моніторингу рівня економічної безпеки підприємства повинні бути такими (рис. 1).

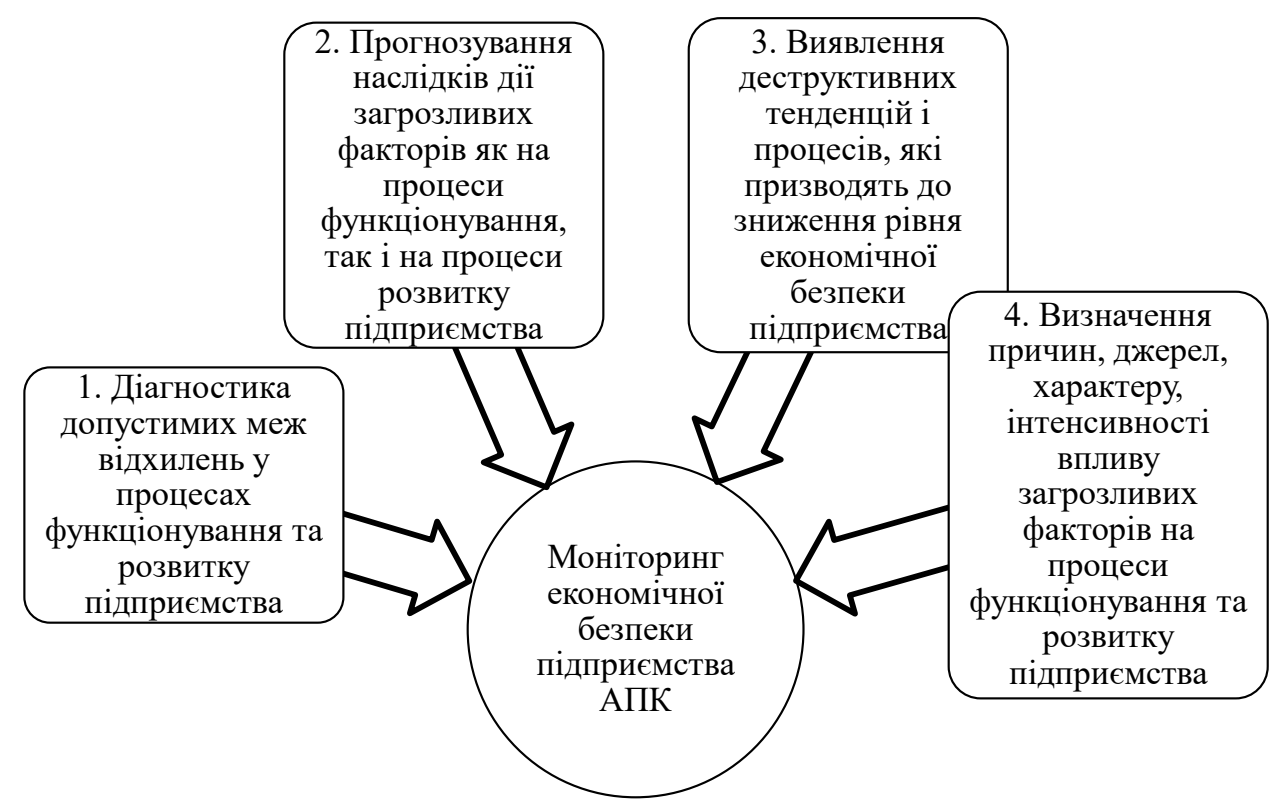

Рис. 1. Етапи моніторингу економічної безпеки підприсмств АПК 
Моніторинг економічної безпеки підприємства має бути результатом взаємодії всіх зацікавлених служб підприємства. Під час здійснення моніторингу має діяти принцип безперервності спостереження за станом об'єкта моніторингу з урахуванням фактичного стану та тенденцій розвитку його потенціалу, а також загального розвитку економіки, політичної обстановки та дії інших загальносистемних факторів.

Для постійного проведення моніторингу економічної безпеки підприємства необхідне відповідне методичне, організаційне, інформаційне та технічне забезпечення [5, с. 67-70].
Висновки. За результатами статті можна зробити висновок, що ми пропонуємо створити на підприємствах АПК окремий підрозділ економічної безпеки та запропонували модель прогнозування загроз стабільності підприємства, яка дає змогу проводити моніторинг та прогнозування внутрішніх та зовнішніх загроз підприємства.

Для підвищення рівня економічної безпеки підприємства важливо впровадити нові якісні рішення у сферу економічної безпеки для реального підвищення іiі рівня.

Всі ці дії допомагають підприємству протистояти внутрішнім та зовнішнім загрозам, уникати їх та складати конкуренцію іншим виробникам на сучасному ринку.

\section{Список літератури:}

1. Акмаєв А.І. Удосконалення оцінки конкурентоспроможності підприємства в умовах глобалізації. Культура народов Причерноморья. 2007. Вип. 99. С. 7-10.

2. Александрова О.В. Економічна стійкість сільськогосподарського виробництва як основний чинник його конкурентоспроможності. Збірник наукових працьь Таврійського держсавного агротехнологічного університету. 2012 . № 2. T. 3. C. $13-21$.

3. Алексеенко Н.В. Устойчивое развитие предприятия как фактор экономического роста. Економіка і організація управління. 2008. Вип. 3. С. 59-65.

4. Бугай В.З., Омельченко В.М. Analysis and evaluation of financial stability of the enterprise. Держава та регіони. 2008. № 1. С. 34-39.

5. Васильчак С.В. Економічна стійкість сільськогосподарських підприємств: стратегічний менеджмент. Формування ринкових відносин в Україні : збірник наукових праць / за ред. І.Г. Мансурова. Вид. 6 (169). 2015. С. 67-70.

\section{References:}

1. Akmaiev A.I. (2007) Udoskonalennia otsinky konkurentospromozhnosti pidpryiemstva v umovakh hlobalizatsii [Improvement of enterprise competitiveness assessment in the conditions of globalization]. Kultura narodov Prychernomoria. Vol. 99, pp. 7-10.

2. Aleksandrova O.V. (2012) Ekonomichna stiikist silskohospodarskoho vyrobnytstva yak osnovnyi chynnyk yoho konkurentospromozhnosti [Economic sustainability of agricultural production as a major factor in its competitiveness]. Zbirnyk naukovykh prats Tavriiskoho derzhavnoho ahrotekhnolohichnoho universytetu, no. 2, t. 3. pp. 13-21.

3. Alekseenko N.V. (2008) Ustoichyvoe razvytye predpryiatyia kak faktor эkonomycheskoho rosta [Sustainable development of the enterprise as a factor of economic growth]. Ekonomika i orhanizatsiia upravlinnia: zb. nauk. pr. Vol. 3, pp. 59-65.

4. Buhai V.Z., Omelchenko V.M. (2008) Analiz ta otsinka finansovoi stiikosti pidpryiemstva [Analysis and evaluation of financial stability of the enterprise]. Derzhava ta rehiony, no. 1, pp. 34-39.

5. Vasylchak S.V. Ekonomichna stiikist silskohospodarskykh pidpryiemstv: stratehichnyi menedzhment [Economic sustainability of agricultural enterprises: strategic management]. Formuvannia rynkovykh vidnosyn v Ukraini, vol. 6 (169), pp. 67-70.

\section{МОНИТОРИНГ ИННОВАЦИОННО-ИНВЕСТИЦИОННОГО ОБЕСПЕЧЕНИЯ ЭКОНОМИЧЕСКОЙ БЕЗОПАСНОСТИ АГРАРНОГО СЕКТОРА}

Принципиальной особенностью развития аграрного производства является взаимосвязь природных, биологических, технологических, организачионных и социальных факторов. Это в значительной степени усиливает появление рисков, которые будут негативно влиять на производство, его экономическую эффективность, финансовые результать и развитие аграрного сектора, что может приводить к снижению конкурентоспособности и финансовой стабильности агропроизводителей. Результативность деятельности производителей аграрного сектора в полной мере зависит от качества оценивания рисков, точности планирования, прогнозирования и предотвращения ситуаций, которые смогут привести к экономическим потерям. Анализ рисковой ситуачии и предупреждение угроз должны давать возможность выбирать оптимальные решения по развитию аграрного производства. Это позволит не только защищать деятельность субъектов хозяйствования от негативных воздействий, но и получать дополнительную прибыль. Формирование экономической безопасности должно стать одной из определяющих составляющих системь обеспечения развития аграрного сектора. При этом концепџия обеспечения безопасности экономической безопасности развития аграрного производства должна рассматриваться как отдельный прочесс системы комплексного подхода к решению проблемных вопросов их защищенности от риска и преодоления угроз. Это полностью указывает на то, что процесс формирования экономической безопасности развития аграрного сектора имеет стратегический характер.

Ключевые слова: инновации, экономическая безопасность, аграрное предприятие, аналитическое обеспечение, инвестиции, оптимизацฺия. 


\section{MONITORING OF INNOVATION AND INVESTMENT SUPPORT OF ECONOMIC SECURITY OF THE AGRICULTURAL SECTOR}

The fundamental features of the development of agricultural production are the relationship between natural, biological, technological, organizational and social factors. This greatly exacerbates the appearance of risks that will adversely affect production, its economic efficiency, financial results and development of the agrarian sector, may lead to a decrease in the competitiveness and financial stability of agricultural producers. The effectiveness of agricultural producers depends on the quality of risk assessment, on the accuracy of planning, forecasting and avoiding situations that can lead to economic losses. The analysis of the risk situation and the prevention of threats should make it possible to choose the best decisions for the development of agricultural production. This will not only protect the activities of the business entities from negative impacts, but also generate additional profits. Formation of economic security should become one of the defining components of the system for ensuring the development of the agricultural sector. At the same time, the concept of ensuring the economic security of the development of agricultural production should be considered as a separate process in the system of an integrated approach to solving the problematic issues of their security risk and overcoming threats. This fully indicates that the process of forming the economic security of agricultural sector development is strategic. Agrarian enterprises are the basic component of the agrarian sector of Ukraine, which is almost the only branch that is able to provide continuous growth of volumes and to improve unfavorable dynamics of economic processes of the country. The sovereignty of the state, ensuring of food and ecological security, creation of socio-economic bases of development of rural territories and assistance in improving the material well - being of the population of the country, as well as the great potential for improving the national economy and its effective integration into the world economic space are all provided by the agrarian sector of Ukraine. The fundamental factor for the efficient operation and sustainable development of agricultural enterprises is the economic security system. Which in turn is designed to prevent and protect businesses from external and internal threats. In today's world, the functioning of educational institutions is extremely dependent on the system of financial and economic security, which raises a great need and interest in implementing new approaches to its organization. Every educational institution, whether public or private, with its financial and economic security system, must meet the dangers and threats of achieving its goals and objectives. Security of electronic digital signatures is an important component of security.

Key words: innovation, economic security, agrarian enterprise, analytical support, investment, optimization. 